\title{
Characteristics of an avirulent Campylobacter jejuni strain and its virulence-enhanced variants
}

\author{
LEANNE H. FIELD, JUDY L. UNDERWOOD, SHELLEY M. PAYNE* and L. J. BERRY
}

Department of Microbiology, The University of Texas at Austin, Austin, Texas 78712-1095, USA

\begin{abstract}
Summary. The virulence of Campylobacter jejuni for 11-day-old chick embryos is associated with the ability to invade the chorio-allantoic membrane, to resist phagocytosis and to survive and proliferate in vivo. The pathogenicity of a well characterised avirulent $C$. jejuni strain was enhanced by passaging it intravenously and chorio-allantoically through chick embryos. The resulting isogenic variants had greatly increased ability to survive in vivo. In this study, the morphological and cell-surface characteristics of the avirulent parental strain were compared with those of the more virulent variants to determine whether pathogenicity was associated with one or more cell-surface constituents. Changes associated with the increased virulence of the two variants included alterations in cultural and cellular morphology, loss of flagella, expression of a new outer-membrane protein, alterations in cell-surface carbohydrates and decreases in cell-surface hydrophobicity.
\end{abstract}

\section{Introduction}

Campylobacter jejuni is an important enteric pathogen in man. Its pathogenicity is incompletely understood, but tissue invasion and toxin production probably play a role in disease. ${ }^{1,2}$ As with other pathogenic micro-organisms, the cell surface of $C$. jejuni interacts directly with the human host, leading to infection and the overwhelming of host defence mechanisms. Structures on the cell surface of $C$. jejuni of potential pathogenic significance include flagella, lipopolysaccharide (LPS) and outer-membrane proteins (OMPs).

C. jejuni is motile by means of a single polar flagellum, and motility facilitates colonisation of the mucous lining of the gastrointestinal tract. ${ }^{3,4,5}$ There is some evidence that flagella also function as adhesins, enabling campylobacters to attach to the epithelial cell surface..$^{6,7}$ Recently, both phase ${ }^{8}$ and antigenic ${ }^{9}$ variation of campylobacter flagella have been reported. Either type of variation may enable the bacterium to avoid the immune response of the host.

In many bacteria, LPS and OMPs play important roles in attachment, invasion, serum resistance, resistance to phagocytosis and the acquisition of iron. ${ }^{10}$ The composition of the outer membrane of $C$. jejuni has been the subject of several studies. ${ }^{11-29}$ Little is known about its potential importance in pathogenesis, but LPS $^{6}$ and several OMPs ${ }^{24,25}$ have been implicated as adhesins.

The 11-day-old chick embryo is a useful in-vivo

Received 15 May 1992; revised version accepted 14 Oct. 1992

* Correspondence should be sent to Professor S. M. Payne. model for the analysis of certain virulence factors in Campylobacter strains. ${ }^{26,27}$ Virulence in this system is associated with the ability to invade the chorioallantoic membrane (CAM), to resist ingestion by phagocytic cells, and to survive and multiply in vivo. ${ }^{26,27}$ In this study, the morphological and cellsurface characteristics of a non-invasive avirulent $C$. jejuni strain and its two, in-vivo passaged, more virulent variants were analysed to determine any possible relationship to pathogenicity.

\section{Materials and methods}

\section{Bacterial strains and cultural conditions}

The isolation and characterisation of $C$. jejuni LOPEZ, a human faecal isolate that is avirulent for 11day-old chick embryos, and the derivation of the more virulent, isogenic variants, LOPEZ-3 and LOPEZ-8, by passage through such embryos, have been described previously. ${ }^{26,27}$ Strains were grown on brucella agar with defibrinated sheep blood $5 \%$ at $37^{\circ} \mathrm{C} .{ }^{27}$ After incubation for $24 \mathrm{~h}$, the growth was harvested and used to inoculate brucella broth-brucella agar biphasic culture medium contained in Erlenmeyer flasks. ${ }^{27}$ The flasks were incubated micro-aerobically without shaking at $37^{\circ} \mathrm{C} .{ }^{27}$

Salmonella typhimurium SL428 (semi-rough; SR) and S. typhimurium SL3749 (chemotype Ra) were kindly provided by Dr K. E. Sanderson, Salmonella Genetic Stock Centre, University of Calgary, Calgary, Alberta, Canada. Salmonella strains were grown aerobically in brucella broth at $37^{\circ} \mathrm{C}$ for $24 \mathrm{~h}$. 


\section{Electronmicroscopy}

Middle to late log-phase cells grown in biphasic medium were fixed with gluteraldehyde $1.5 \%$, stained with uranyl acetate $1.5 \%$, and examined with a JEOL $100 \mathrm{CX}$ electronmicroscope.

\section{Hydrophobic interaction chromatography}

The method of Smyth et al. ${ }^{28}$ was used to compare the surface hydrophobicity of $C$. jejuni strains. Briefly, sterile pasteur pipettes were packed by gravity feed to a height of $30 \mathrm{~mm}$ with Octyl Sepharose C1-4B (Pharmacia). Gel beds were washed with $10 \mathrm{ml}$ of $1 \mathrm{M}$ ammonium sulphate buffered with $10 \mathrm{~mm}$ sodium phosphate, pH 6.8, (buffer A). The entire chromatography procedure was performed at room temperature.

Middle to late log-phase cells grown in biphasic medium were harvested by centrifugation and resuspended in buffer A to a turbidity of 500 Klett units (green filter). Portions $(100 \mu \mathrm{l})$ of the bacterial suspension were placed on the gel beds and in a control tube containing $5 \mathrm{ml}$ of buffer A. Gel beds were washed with $5 \mathrm{ml}$ of buffer $A$ and the eluates were collected in sterile tubes. The number of cfu present in each eluate and in the control tubes was determined by plating serial 10-fold dilutions. The percentage (mean value of three samples) of adsorbed bacteria was calculated by the following formula: (cfu in the control-cfu in the eluate $) /($ cfu in the control $) \times 100$. Each strain was tested in triplicate, and experiments were repeated once.

\section{Preparation of outer membranes}

C. jejuni cells were fractionated to prepare outer membranes by a procedure previously shown to yield outer membranes uncontaminated by other cell constituents. ${ }^{29}$ Briefly, cultures of middle to late log-phase cells grown in biphasic medium were harvested by centrifugation, and the cell pellets were frozen at $-20^{\circ} \mathrm{C}$ for at least $24 \mathrm{~h}$. The procedure of Inouye and Guthrie $^{30}$ was used to prepare total cell envelopes, as follows. The cells ( $1 \mathrm{~g}$, wet weight) were resuspended in $10 \mathrm{ml}$ of $10 \mathrm{~mm}$ sodium phosphate buffer ( $\mathrm{pH} \mathrm{7.0)}$ containing $5 \mathrm{mM} \mathrm{MgSO}_{4}$. DNAase I (Sigma) was added to a concentration of $10 \mu \mathrm{g} / \mathrm{ml}$, and cells were disrupted ultrasonically. The preparation was centrifuged at low speed to remove unlysed cells. The total membrane fraction was collected by centrifuging the supernate at $100000 \mathrm{~g}$ at $20^{\circ} \mathrm{C}$ for $45 \mathrm{~min}$ (L8-M ultracentrifuge; Beckman Instruments Inc., Fullerton, CA, USA). Outer membranes were prepared by the method of Filip et al., ${ }^{31}$ in which treatment with Sarkosyl (Ciba-Geigy Corp., Summit, NJ, USA) $1 \%$ for $30 \mathrm{~min}$ was used to solubilise the inner membrane.

\section{SDS-PAGE of outer membranes}

Outer membranes were solubilised in Laemmli solubilisation buffer, ${ }^{32}$ heated at $100^{\circ} \mathrm{C}$ for $5 \mathrm{~min}$, and the polypeptides were separated by the SDS-PAGE system of Ames $^{33}$ as described previously. ${ }^{29}$ Stacking and separating gels consisted of acrylamide $5 \% \mathrm{w} / \mathrm{v}$ and $10 \% \mathrm{w} / \mathrm{v}$, respectively. Gels were stained with Coomassie Brilliant Blue R (Sigma), destained and dried. Protein standards were: phosphorylase $b$ (94 kDa), albumin (67 kDa), catalase (60 kDa), ovalbumin $(43 \mathrm{kDa})$, carbonic anhydrase $(30 \mathrm{kDa})$, trypsin inhibitor $(20 \cdot 1 \mathrm{kDa})$ and $\alpha$-lactalbumin $(14.4 \mathrm{kDa})$ (Pharmacia Fine Chemicals, Piscataway, NJ, USA).

\section{LPS analysis}

Proteinase K-digested whole cell lysates were used as the source of LPS for analysis by SDS-PAGE. Lysates were prepared by a modification of the procedure described by Kimura and Hansen. ${ }^{34}$ Briefly, middle to late log-phase cells grown in biphasic medium were harvested by centrifugation and the pelleted cells were resuspended in phosphate-buffered saline (PBS). This suspension was centrifuged at $7000 \mathrm{~g}$ for $10 \mathrm{~min}$ and the cell pellet was resuspended in PBS. The bacteria were solubilised by adding 0.5 volume of $3 \times$ concentrated digestion buffer (SDS $6 \% \mathrm{w} / \mathrm{v}$, glycerol $30 \% \mathrm{v} / \mathrm{v}, 0 \cdot 1875 \mathrm{M}$ Tris- $\mathrm{HCl}, \mathrm{pH} \mathrm{6.8}$, and Pyronin $\mathrm{Y}$ tracking dye $(0.015 \% \mathrm{w} / \mathrm{v})$. Lysates were heated at $100^{\circ} \mathrm{C}$ for $10 \mathrm{~min}$, divided into multiple small volumes and stored at $-20^{\circ} \mathrm{C}$ for a maximum of 2 weeks.

For LPS analysis, a $20-\mu$ l portion of each lysate was diluted with $20 \mu$ of digestion buffer consisting of SDS $0.1 \% \mathrm{w} / \mathrm{v}$, glycerol $10 \% \mathrm{v} / \mathrm{v}, 0.0625 \mathrm{M}$ Tris- $\mathrm{HCl}$, pH 6.8, and Pyronin Y 0.005\% w/v. Proteins were digested by adding $10 \mu \mathrm{l}$ of a digestion buffer containing proteinase $\mathrm{K}$ (Sigma) $2 \mathrm{mg} / \mathrm{ml}$ and incubating for $1 \mathrm{~h}$ at $60^{\circ} \mathrm{C}$. All samples were heated at $100^{\circ} \mathrm{C}$ for $5 \mathrm{~min}$ immediately before being loaded into the wells for electrophoresis. Purified LPS from the Ra and $\mathrm{Rb}$ chemotypes of $S$. minnesota was purchased from List Biological Laboratories Inc., Campbell, CA, USA.

LPS preparations were analysed by discontinuous SDS-PAGE $^{33}$ with the Laemmli buffer system ${ }^{32}$ as described by Kimura and Hansen. ${ }^{34}$ The separating gel consisted of a linear polyacrylamide gradient $10-15 \%$ $\mathrm{w} / \mathrm{v}$ containing a linear glycerol gradient $0-37.5 \%$ $\mathrm{v} / \mathrm{v}$. The stacking gel contained polyacrylamide $4 \%$ $\mathrm{w} / \mathrm{v}$. Electrophoresis was performed at $4^{\circ} \mathrm{C}$ with a $20 \mathrm{~mA}$ constant current. After electrophoresis, the gels were fixed, and the LPS was visualised by the silver stain technique of Tsai. ${ }^{35}$

\section{Lectin agglutination}

The sources of 14 lectins contained in panels (E.Y. Laboratories, San Mateo, CA, USA) were: Canavalia ensiformis (concanavalin A), Lens culinaris (lentil lectin), Solanum tuberosum (potato starch agglutinin), Triticum vulgare (wheat germ agglutinin), Griffonia simplicifolia II, Dolichos bifloris, Helix pomatia, Glycine max (soybean agglutinin), Arachis hypogeae (pea- 
nut agglutinin), Griffonia simplicifolia I, Trichosanthes kinlowii, Ulex europaeus I, Limax flavus and Phaseolus vulgaris. The specificities of these lectins have been described previously. ${ }^{36,37}$ Bacterial interaction with the lectins was tested as follows: $C$. jejuni strains were grown in biphasic medium and harvested by centrifugation. Cell pellets were resuspended in $10 \mathrm{ml}$ of Tris-buffered saline ( $10 \mathrm{~mm}$ Tris, $0.13 \mathrm{M} \mathrm{NaCl}, \mathrm{pH} 7.4$; TBS). The cultures were heated at $100^{\circ} \mathrm{C}$ for $1 \mathrm{~h}$ to enhance their reactivity with lectins and to eliminate non-specific agglutination reactions. ${ }^{38}$ The heated cells were washed once with TBS and then resuspended in TBS containing DNAase I (Sigma) $10 \mu \mathrm{g} / \mathrm{ml}$ to a turbidity of 180 units $\left(10^{8}-3 \times 10^{9}\right.$ organisms $\left./ \mathrm{ml}\right)$ as measured in a Klett-Summerson colorimeter (Klett Manufacturing Co., NY, USA) fitted with a green filter. Cell suspensions were then checked for autoagglutination under a dissecting microscope. Bacterial suspension $(100 \mu \mathrm{l})$ was added to each lectin well, and the lectin panels were rotated $(80 \mathrm{rpm})$ on a shaker. Cell agglutination was examined under a dissecting microscope after 5,15 and $30 \mathrm{~min}$.

\section{Statistical analysis}

Statistical significance was determined by the Student's $t$ test.

\section{Results}

\section{Virulence of $C$. jejuni strains and passaged variants for chick embryos}

Previous reports described the virulence of human isolates for 11-day-old chick embryos inoculated via the chorio-allantoic and intravenous routes. ${ }^{26,27}$ Highly virulent strains invaded the CAM, resisted phagocytosis, and proliferated. Avirulent strains were non-invasive. A well characterised avirulent strain, LOPEZ, became more virulent during intravenous or chorio-allantoic passage. ${ }^{26}$ The resulting isogenic variants (LOPEZ-3 and -8) did not invade the CAM but were more successful than LOPEZ at resisting phagocytosis and surviving in vivo, as shown by 3.3 and $3.9 \log _{10}$ decreases, respectively, in LD50 $72 \mathrm{~h}$ after intravenous inoculation. ${ }^{26}$ After an intravenous dose of $10^{4}$ campylobacters, LOPEZ-3 exhibited a reduced initial clearance from the blood as compared with LOPEZ, and an increased ability to multiply in blood and liver. ${ }^{26}$ Thus, these variants afforded a means of studying virulence determinants associated with survival apart from those related to invasion.

\section{Cultural and morphological differences in C. jejuni LOPEZ and its more virulent variants LOPEZ-3 and -8}

In liquid suspensions of $C$. jejuni LOPEZ prepared using growth from agar plates, the suspended cells invariably "settled out" to the bottom of the tube within $30 \mathrm{~min}$. The parental strain also grew in clumps in biphasic culture medium. In contrast, liquid suspensions of the two variants, LOPEZ-3 and -8, did not "settle out", and both grew as smooth suspensions in biphasic culture medium.

Examination of middle to late log-phase growth in biphasic medium gave further information. Gramstained smears showed that passage in vivo progressively selected for cells which were thin and rod-shaped, rather than the typical spiral-shaped campylobacter cells. The percentage of thin, rod-shaped cells was $6 \cdot 1$, 39 and $99.9 \%$ respectively in LOPEZ, LOPEZ-3, and LOPEZ-8; transmission electronmicroscopy showed that LOPEZ cells alone were flagellate (figs. 1A, B and C). The motility of each isolate was investigated by plating biphasic cultures in soft-agar pour plates and examining at least 1000 colonies. Only the large diffuse colonies characteristic of motile cells were seen in LOPEZ (fig. 1D). In LOPEZ-3 cultures, two colony types occurred, $99 \%$ were small and opaque and $1 \%$ slightly larger and opaque (fig. 1E); neither type was surrounded by the diffuse halo of growth that indicated motility. In LOPEZ-8 cultures, all colonies were small and opaque (fig. 1F).

Like the parent strain, the more virulent variants were oxidase- and catalase-positive, sensitive to nalidixic acid and resistant to cephalothin, grew at $37^{\circ} \mathrm{C}$ and $42^{\circ} \mathrm{C}$ but not at $25^{\circ} \mathrm{C}$, and hydrolysed hippurate. Older cultures of the variants grown on agar plates or in biphasic medium underwent the expected gradual conversion from spiral or rod-shaped forms to a predominance of coccal forms.

Strain LOPEZ and its two variants grew in biphasic medium at approximately the same rate between 0 and $6 \mathrm{~h}$ after inoculation, doubling once every $3 \cdot 2 \mathrm{~h}$. Between 6 and $9 \mathrm{~h}$ after inoculation, LOPEZ grew faster (doubling once every $1.8 \mathrm{~h}$ ) than LOPEZ-3 and -8 (doubling times $4.3 \mathrm{~h}$ and $5 \mathrm{~h}$, respectively). The growth rate of all three slowed from 9 to $28 \mathrm{~h}$ after inoculation. The final cell densities of LOPEZ-3 and -8 reached only half that of the parent strain. Therefore, the increased survival of the more virulent variants in vivo was not the result of a more rapid growth rate.

\section{Cell-surface analysis of C. jejuni LOPEZ and its more virulent variants}

This was undertaken to determine whether the increased virulence of the variants could be associated with components of the campylobacter cell envelope.

Cell-surface hydrophobicity. Because virulence in the chick embryo is associated with the ability to avoid phagocytosis, ${ }^{26}$ and because cell-surface hydrophobicity influences phagocytosis, ${ }^{39-42}$ the relative cellsurface hydrophobicity of strain LOPEZ and its two variants was determined by hydrophobic interaction chromatography. Each organism was passed through a column of the hydrophobic gel Octyl Sepharose, and the percentage of bacteria which adsorbed to the gel was determined. The percentages for LOPEZ, LOPEZ-3 and -8 were 70.0 (SEM 3.5), 37.3 (SEM 6.3) 

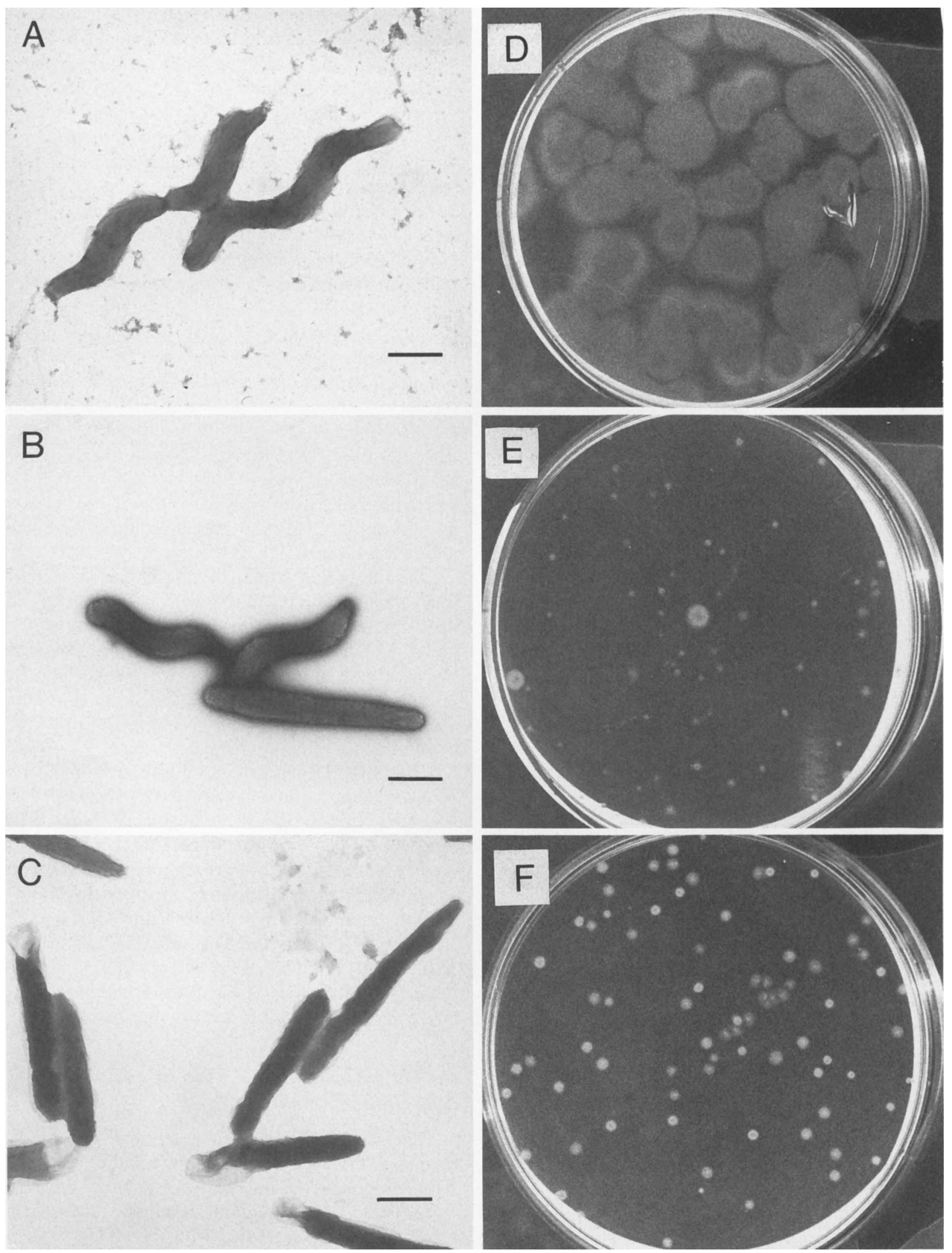

Fig. 1. Motility characteristics of $C$. jejuni LOPEZ, and its isogenic, more virulent variants, LOPEZ-3 and -8 . Representative electronmicrographs of middle to late log-phase cells of C. jejuni LOPEZ (A), LOPEZ-3 (B), and -8 (C) grown in biphasic culture medium Bar, 0-5 $\mu \mathrm{m}$. Appearance of $C$, jejuni LOPEZ(D), LOPEZ-3 (E), and -8 (F) in soft-agar pour plates. Each isolate was grown in biphasic culture medium and appropriate dilutions were inoculated into brucella broth containing agar $0.5 \%$. Plates were photographed after incubation for $48 \mathrm{~h}$ at $37^{\circ} \mathrm{C}$.

and 28.4 (SEM 6.1) respectively, indicating that passage of strain LOPEZ through chick embryos had selected for variants with decreased cell-surface hydrophobicities. This suggested that the cell-surface hydro- phobicity of strain LOPEZ contributed to its susceptibility to phagocytosis. ${ }^{26}$ Recent studies by Tompkins $^{43}$ have shown that the absence of flagella does not significantly affect the cell-surface hydro- 


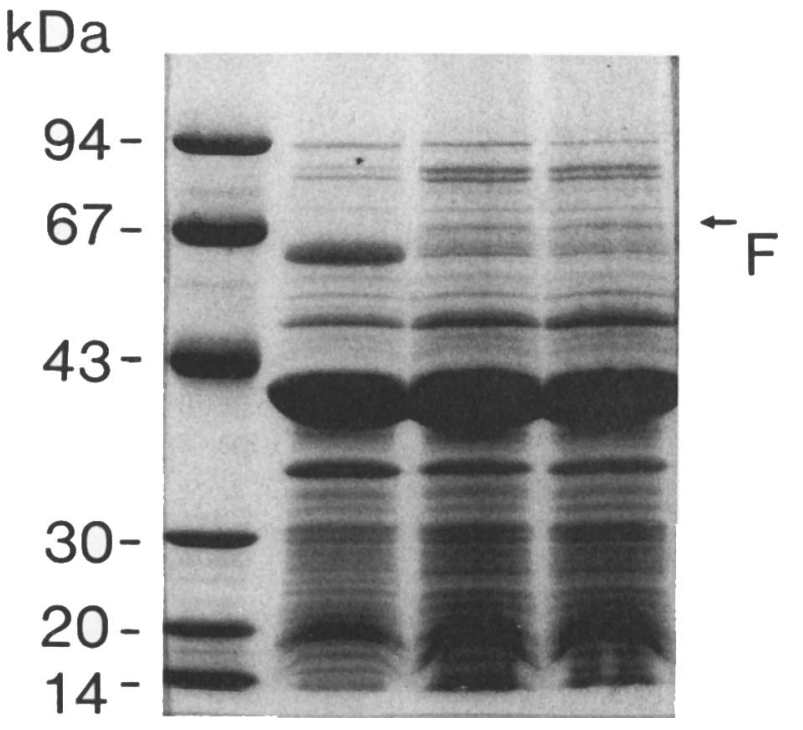

Fig. 2. SDS-PAGE of outer-membrane proteins of $C$. jejuni LOPEZ (latse 1), LOPEZ-3 (2), and -8 (3). Mol. wt markers are shown on the left. The arrow indicates the position of the $71.4 \mathrm{kDa}$ protein which is present in the profiles of $C$. jejuni LOPEZ-3 and -8, but absent from strain LOPEZ. The polypeptide band which corresponds to flagellin is indicated by the letter F.

phobicity of $C$. jejuni. Therefore, the decreased hydrophobicity of the variants probably reflected changes in the OMPs or LPS rather than loss of flagella.

Outer-membrane proteins. SDS-PAGE profiles of C. jejuni LOPEZ and its two variants were similar to those reported for other $C$. jejuni strains. ${ }^{12,13}$ The profiles are dominated by a single major OMP band (fig. 2) of $40 \mathrm{kDa}$. Other investigators have reported that a major OMP of $40-46 \mathrm{kDa}$ is characteristic of $C$. jejuni and $C$. coli strains. ${ }^{2,20}$ A significant amount of a second protein $(65 \mathrm{kDa})$ was seen in the profile of strain LOPEZ but was greatly diminished in the profiles of LOPEZ-3 and -8. Logan and Trust ${ }^{13}$ and Newell et $a .^{18}$ identified proteins of similar size as flagellin. Since the variants were non-flagellate, the faint band, which migrated at approximately the same position as flagellin, may have been a co-migrating protein or flagellin in greatly reduced quantity.

One protein $(71.4 \mathrm{kDa})$ was present in the profiles of LOPEZ-3 and -8 but absent from strain LOPEZ (arrow, fig. 2). Other bands, corresponding to proteins of 80.2 and $85.5 \mathrm{kDa}$, were enhanced in intensity in the profiles of the two variants. Therefore, passage of the avirulent strain LOPEZ produced more virulent isogenic variants with altered OMPs.

$L P S$ analysis by SDS-PAGE. The LPS structures of $C$. jejuni LOPEZ and its more virulent variants were compared by analysing proteinase $\mathrm{K}$-treated wholecell lysates by SDS-PAGE and visualising the bands with silver staining. Purified LPS from the Ra and Rb chemotypes of $S$. minnesota, and proteinase Kdigested whole-cell lysates from smooth, SR and the $\mathrm{Ra}$ chemotype of $S$. typhimurium were included as mol.-wt markers. The profiles of each isolate showed a prominent fast-migrating band, which is typically seen with a rough-type LPS (data not shown). None of the profiles appeared to have bands corresponding to
Table. The agglutination of $C$. jejuni LOPEZ and its two virulent variants by lectins

\begin{tabular}{lcc} 
& \multicolumn{2}{c}{ Agglutination by lectins* from } \\
\cline { 2 - 3 } Strain & Limax flavus & Helix pomatia \\
\hline LOPEZ & + & - \\
LOPEZ-3 & + & wk \\
LOPEZ-8 & + & + \\
\hline
\end{tabular}

- , No agglutination; + , strong agglutination; wk, weak agglutination.

* Lectin specificities according to Goldstein and Poretz, ${ }^{36}$ Slifkin and Doyle, ${ }^{37}$ and commercial literature of E-Y Laboratories: Limax flavus, $\mathrm{N}$-acetylneuraminic acid $>\mathrm{N}$-glycolylneuraminic acid; Helix pomatia, $\mathrm{N}$-acetylgalactosamine $\alpha$ 1,3 $\mathrm{N}$-acetylgalactosamine $>$ $\mathrm{N}$-acetylgalactosamine $>\mathrm{N}$-acetylglucosamine $>$ galactose .

high-mol.-wt forms of LPS, although such bands from wild-type $S$. typhimurium could be identified in the gels (data not shown). There were no apparent differences in relative migration of the LPS from LOPEZ, LOPEZ-3 or -8 and the mobility of each appeared to be identical with that of purified LPS from the $\mathrm{Ra}$ chemotype of $S$. minnesota and with proteinase Kdigested whole-cell lysates of the Ra mutant of $S$. typhimurium.

Interaction with lectins. Passage of strain LOPEZ did not appear to select for variants with different mol.-wt forms of LPS, but this did not eliminate the possible existence of subtle structural differences in the oligosaccharide moieties. Therefore, the interaction of these organisms with various lectins was investigated. Interactions with lectins have been used to provide preliminary information about the polysaccharide components present in the cell envelopes of various gram-negative bacteria, ${ }^{36,44,45}$ including $C$. jejuni. ${ }^{37,46,47} C$. jejuni LOPEZ and its two variants were unreactive with 12 of the 14 lectins tested-those derived from Arachis hypogeae, Canavalia ensiformis, Dolichos bifloris, Glycine max, Griffonia simplicifolia I, Griffonia simplicifolia II, Lens culinaris, Phaseolus vulgaris, Solanum tuberosum, Trichosanthes kinlowii, Triticum vulgare, and Ulex europaeus I (data not shown).

All three organisms were agglutinated by the lectin derived from Limax flavus, indicating the presence of sialic acid on their cell surfaces (table). However, unlike the parental strain, the isogenic variants were agglutinated by the lectin from Helix pomatia, suggesting that terminal, non-reducing $\mathrm{N}$-acetylgalactosamine groups were present on the cell surfaces of these organisms. These results indicate that passage of strain LOPEZ produced variants with modified cell-surface carbohydrates.

\section{Discussion}

Previous studies established that the virulence of $C$. jejuni for chick embryos is associated with the ability to invade the chorio-allantoic membrane, to avoid phagocytosis, and to survive and multiply in vivo, ${ }^{26,27}$ 
but not with carriage of plasmid DNA, siderophore production, bacterial motility or cell-envelope toxicity. ${ }^{27}$ Although this model does not closely mimic intestinal disease in mammals and does not allow an examination of early events such as colonisation, it provides a useful system for the study of invasion, resistance to phagocytosis and growth in vivo. The present studies focused on the cultural, morphological and cell-surface properties of a well characterised avirulent non-invasive $C$. jejuni strain and two isogenic variants obtained by passage in vivo to determine whether virulence could be associated with one or more components of the campylobacter cell envelope.

Motility was shown previously to play little role in the ability of invasive $C$. jejuni to cross the CAM of chick embryos and survive in vivo. These results confirm that flagella are not required for the survival of campylobacters in the chick embryo. ${ }^{22}$ Aflagellate forms progressively increased when $C$. jejuni LOPEZ was passaged intravenously through embryos. The isogenic variant LOPEZ-3 was non-motile in soft-agar pour plates and non-flagellate as determined by electronmicroscopy. When $C$. jejuni LOPEZ-3 was subjected to additional chorio-allantoic passages, the phenotype of the resulting variant (LOPEZ-8) remained non-motile. Therefore, flagella are unnecessary for growth in the chick embryo.

In a recent review, $S$ mith ${ }^{48}$ pointed out that the behaviour of micro-organisms in vivo is determined both by genetic make-up and environment. Selection and phenotypic change may occur when pathogens are moved from one type of environment to another. Selection for non-motile forms in vivo is not without precedent. Luzar and colleagues ${ }^{49}$ reported that strains of Pseudomonas aeruginosa isolated from the lungs of patients with cystic fibrosis are frequently non-motile and non-chemotactic. These authors suggest that after initial pulmonary invasion, there is progressive host selection against bacterial properties normally associated with invasion, such as motility and chemotaxis. The present study suggests that such a selective pressure occurs in the chick embryo.

These findings do not negate the importance of motility in the viscous environment of the gastrointestinal tract where both the spiral shape and propulsion by flagella give campylobacter cells a selective advantage.$^{3-5,50}$ However, there is little evidence to support a role for this cell-surface structure in invasion or extra-intestinal survival and proliferation.

In addition to the loss of flagella, other cell-surface changes were associated with the enhanced virulence of the two passaged variants, including alteration in cultural characteristics, cellular morphology, cell-surface hydrophobicity, OMPs and cell-surface carbohydrates. It is difficult to assess which of these changes directly contributed to the enhanced survival of $C$. jejuni LOPEZ-3 and -8 in vivo. However, since surface hydrophobicity facilitates phagocytosis, ${ }^{39,40,41,42}$ it is likely that the decreased cell-surface hydrophobicity of the variants contributed to their ability to avoid phagocytosis.

Changes in the OMP or LPS composition of the variants may have contributed to their decreased cellsurface hydrophobicity. At least one new protein $(71.4 \mathrm{kDa})$ was expressed in the outer membrane of LOPEZ-3 and -8. Two additional OMPs $(80 \cdot 2$ and $85.5 \mathrm{kDa}$ ) present in strain LOPEZ were found in greater amounts in the passaged variants. One or more of these proteins may have hydrophilic properties which help in preventing phagocytosis.

In-vivo passage of $C$. jejuni LOPEZ did not appear to have selected isogenic variants with LPS of different mol. wt, but subtle alterations in LPS structure may nonetheless have occurred. Indeed, the observation that the two variants reacted with a lectin with which the parental strain was unreactive suggests an alteration in cell-surface carbohydrates. Recent studies have demonstrated that sialic acid is linked to $C$. jejuni LPS. $^{21,22}$ Sialylation of gonococcal LPS in vivo by a host substrate, CMP-N-acetylneuraminic acid, has been shown to confer serum resistance on this pathogen. ${ }^{48}$ While sialic acid was detected on the cell surface of $C$. jejuni LOPEZ and its variants, it was the presence of $\mathrm{N}$-acetylgalactosamine on the surface of the latter which seemed to correlate with virulence in vivo. A more complete chemical analysis of the LPS of the organisms is required to confirm this finding.

The significance of the morphological alterations which occurred when strain LOPEZ was passaged through the embryos is unclear. Certainly, C. jejuni is a pleomorphic micro-organism, which is known to undergo a morphological change from curved or spiral forms in young cultures to coccal forms in older cultures. ${ }^{51,52}$ However, in-vivo selection of rod-shaped cells from spiral forms had not previously been reported. It is unlikely that this morphological alteration was related to the loss of flagella, since loss of flagella either in natural variants or in FlaA or FlaB mutants does not result in rod-shaped cells. ${ }^{53,54}$ When non-motile clones of some $C$. jejuni strains are repeatedly subcultured in soft agar, rod-shaped cells sometime arise. However, the reason that nonflagellate rod-shaped cells (LOPEZ-8) were progressively selected in vivo from a mixed population containing both non-flagellate rod-shaped and nonflagellate spiral cells (LOPEZ-3) remains to be elucidated. Presumably, cells with the altered cellular morphology had a selective advantage in the embryonic host.

The virulence of $C$. jejuni in the chick embryo appears to be relatively complex. Successful multiplication in vivo is clearly associated with the ability to resist phagocytosis. Several cell-surface changes may contribute to the enhanced virulence of variants produced by passage through chick embryos, including alterations in cellular morphology, decreases in cell-surface hydrophobicity, changes in the OMPs and alterations in cell-surface carbohydrates. 
We thank Amy Pavone, Xuan T. Thai and F. Taylor for their excellent technical assistance, D. Brown, of this department, for performing the electronmicroscopy, and E. Hanson for advice on

\section{References}

1. Cover TL, Blaser MJ. The pathobiology of Campylobacter infections in humans. Annu Rev Med 1989; 40: 269-285.

2. Walker RI, Caldwell MB, Lee EC, Guerry P, Trust TJ, RuizPalacios GM. Pathophysiology of Campylobacter enteritis. Microbiol Rev 1986; 50: 81-94.

3. Lee A, O'Rourke JL, Barrington PJ, Trust TJ. Mucus colonization as a determinant of pathogenicity in intestinal infection by Campylobacter jejuni: a mouse cecal model. Infect Immun 1986; 51: 536-546.

4. Morooka T, Umeda A, Amako K. Motility as an intestinal colonization factor for Campylobacter jejuni. J Gen Microbiol 1985; 131 : 1973-1980.

5. Aguero-Rosenfeld ME, Yang X-H, Nachamkin I. Infection of adult Syrian hamsters with flagellar variants of Campylobacter jejuni. Infect Immun 1990; 58: 2214-2219.

6. McSweegan E, Walker RI. Identification and characterization of two Campylobacter jejuni adhesins for cellular and mucous substrates. Infect Immun 1986; 53: 141-148.

7. Newell DG, McBride H, Dolby JM. Investigations on the role of flagella in the colonization of infant mice with Campylobacter jejuni and attachment of Campylobacter jejuni to human epithelial cell lines. $J$ Hyg 1985; 95: 217-227.

8. Caldwell MB, Guerry P, Lee EC, Burans JP, Walker RI. Reversible expression of flagella in Campylobacter jejuni. Infect Immun 1985; 50: 941-943.

9. Harris LA, Logan SM, Guerry P, Trust TJ. Antigenic variation of Campylobacter flagella. $J$ Bacteriol 1987; 169: 5066-5071.

10. Buchanan TM, Pearce WA. Pathogenic aspects of outer membrane components of gram-negative bacteria. In: Inouye $\mathbf{M}$ (ed) Bacterial outer membranes: biogenesis and functions. New York, John Wiley and Sons. 1979:475-514.

11. Beer W, Adam M, Seltmann G. Monosaccharide composition of lipopolysaccharides from Campylobacter jejuni and Campylobacter coli. J Basic Microbiol 1986; 26: 201-204.

12. Blaser MJ, Hopkins JA, Berka RM, Vasil ML, Wang W-L L. Identification and characterization of Campylobacter jejuni outer membrane proteins. Infect Immun 1983; 42: 276-284.

13. Logan SM, Trust TJ. Outer membrane characteristics of Campylobacter jejuni. Infect Immun 1982; 38: 898-906.

14. Logan SM, Trust TJ. Structural and antigenic heterogeneity of lipopolysaccharides of Campylobacter jejuni and Campylobacter coli. Infect Immun 1984; 45: 210-216.

15. Naess $\mathrm{V}$, Hofstad $T$. Isolation and chemical composition of lipopolysaccharide from Campylobacter jejuni. APMIS $1982 ; 90: 135-139$.

16. Naess V, Hofstad T. Chemical composition and biological activity of lipopolysaccharides prepared from type strains of Campylobacter jejuni and Campylobacter coli. APMIS 1984; 92: 217-222.

17. Naess V, Hofstad T. Chemical studies of partially hydrolyzed lipopolysaccharides from four stains of Campylobacter jejuni and two strains of Campylobacter coli. J Gen Microbiol 1984; 130: 2783-2789.

18. Newell DG, McBride H, Pearson AD. The identification of outer membrane proteins and flagella of Campylobacter jejuni. J Gen Microbiol 1984; 130: 1201-1208.

19. Perez Perez GI, Blaser MJ. Lipopolysaccharide characteristics of pathogenic campylobacters. Infect Immun 1985; 47: 353-359.

20. Trust TJ, Logan SM. Outer membrane and surface structure of Campylobacter jejuni. In: Butzler JP (ed) Campylobacter infection in man and animals. Boca Raton, FL, CRC Press, Inc. $1984 ; 133-142$

21. Moran AP, Rietschel ET, Kosunen TU, Zähringer U. Chemical characterization of Campylobacter jejuni lipopolysaccharidescontaining $\mathrm{N}$-acetylneuraminic acid and 2,3-diamino2,3-dideoxy-D-glucose. J Bacteriol 1991; 173: 618-626.

22. Mills SD, Aspinall GO, McDonald AG, Raju TS, Kurjanczyk LA, Penner JL. Lipopolysaccharide antigens of Campylobacter jejuni. In: Nachamkin I, Blaser MJ, Tompkins LS (eds) Campylobacter jejuni-current status and future analysing LPS by SDS-PAGE. This research was supported by Public Health Service grant AI-18425 from the National Institute of Allergy and Infectious Diseases to L. J.B.

trends. Washington, DC. American Society for Microbiology 1992: 232-229.

23. Pei Z, Ellison RT, Blaser, MJ. Identification, purification, and characterization of major antigenic proteins of Campylobacter jejuni. J Biol Chem 1991; 266: 16363-16369.

24. De Melo MA, Pechère J-C. Identification of Campylobacter jejuni surface proteins that bind to eucaryotic cells in vitro. Infect Immun 1990; 58: 1749-1756.

25. Fauchere JL, Kervella M, Roseenau A, Pages JM, Fendri C. In vitro study of virulence factors of enteric Campylobacter spp. In: Nachamkin I, Blaser MJ, Tompkins LS (eds) Campylobacter jejuni-current status and future trends. Washington, DC. American Society for Microbiology 1992: 168-175.

26. Field LH, Underwood JL, Payne SM, Berry LJ. Virulence of Campylobacter jejuni for chicken embryos is associated with decreased bloodstream clearance and resistance to phagocytosis. Infect Immun 1991; 59: 1448-1456.

27. Field LH, Headley VL, Underwood JL, Payne SM, Berry LJ. The chicken embryo as a model for Campylobacter invasion: comparative virulence of human isolates of Campylobacter jejuni and Campylobacter coli. Infect Immun 1986; 54: 118-125.

28. Smyth CJ, Jonsson $\mathbf{P}$, Olsson E et al. Differences in hydrophobic surface characteristics of porcine enteropathogenic Escherichia coli with or without $\mathrm{K} 88$ antigen as revealed by hydrophobic interaction chromatography. Infect Immun $1978 ; 22: 462-472$

29. Field LH, Headley VL, Payne SM, Berry LJ. Influence of iron on growth, morphology, outer membrane protein composition, and synthesis of siderophores in Campylobacter jejuni. Infect Immun 1986; 54: 126-132.

30. Inouye $\mathrm{M}$, Guthrie JP. A mutation which changes a membrane protein of E. coli. Proc Natl Acad Sci USA 1969; 64: 957-961.

31. Filip C, Fletcher G, Wulf JL, Earhart CF. Solubilization of the cytoplasmic membrane of Escherichia coli by the ionic detergent sodium-lauryl sarcosinate. $J$ Bacteriol 1973 ; 115: 717-722.

32. Laemmli UK. Cleavage of structural proteins during the assembly of the head of bacteriophage T4. Nature 1970; 227: $680-685$.

33. Ames GF-L. Resolution of bacterial proteins by polyacrylamide gel electrophoresis on slabs. Membrane, soluble and periplasmic fractions. $J$ Biol Chem $1974 ; 249 ; 634-644$.

34. Kimura A, Hansen EJ. Antigenic and phenotypic variations of Haemophilus influenzae type b lipopolysaccharide and their relationship to virulence. Infect Immun 1986; 51: 69-79.

35. Tsai C-M. The analysis of lipopolysaccharide (endotoxin) in meningococcal polysaccharide vaccines by silver staining following SDS-polyacrylamide gel electrophoresis. J Biolog Stand 1986; 14: 25-33.

36. Goldstein IJ, Poretz RD. Isolation, physicochemical characterization, and carbohydrate-binding specificity of lectins. In: Liener IE, Sharon N, Goldstein IJ (eds) The lectinsproperties, functions, and applications in biology and medicine. New York, Academic Press, Inc. 1986: 33-247.

37. Slifkin M, Doyle RJ. Lectins and their application to clinical microbiology. Clin Microbiol Rev 1990; 3: 197-218.

38. Wong KH, Skelton SK, Feeley JC. Strain characterization and grouping of Campylobacter jejuni and Campylobacter coli by interaction with lectins. $J$ Clin Microbiol 1986; 23 : $407-410$.

39. van Oss CJ. Phagocytosis as a surface phenomenon. Annu Rev Microbiol 1978; 32: 19-40.

40. van Oss CJ, Gillman CF, Neumann AW. Phagocytic engulfment and cell adhesiveness. New York, Marcel Dekker, Inc. 1975.

41. Ofek I, Rest RF, Sharon N. Nonopsonic phagocytosis of microorganisms. ASM News 1992; 58: 429-435.

42. Ohman L, Maluszynska G, Magnusson K-E, Stendahl O. Surface interaction between bacteria and phagocytic cells. Prog Drug Res 1988; 32: 131-147.

43. Tompkins LS. Genetic and molecular approaches to Campylo- 
bacter pathogenesis. In: Nachamkin I, Blaser MJ, Tompkins LS (eds) Campylobacter jejuni-current status and future trends. Washington, DC. American Society for Microbiology 1992: 241-254.

44. Lis H, Sharon N. Lectins as molecules and tools. Annu Rev Biochem 1986; 55: 35-67.

45. Pistole TG. Interaction of bacteria and fungi with lectins and lectin-like substances. Annu Rev Microbiol 1981; 35: $85-112$.

46. Corbel MJ, Gill KPW. Lectin agglutination of thermophilic Campylobacter species. Vet Microbiol 1987; 15: 163-173.

47. Wong KH, Skelton SK, Feeley JC. Interaction of Campylobacter jejuni and Campylobacter coli with lectins and blood group antibodies. $J$ Clin Microbiol 1985; 22: 134-135.

48. Smith H. Pathogenicity and the microbe in vivo. J Gen Microbiol 1990; 136: 377-383.

49. Luzar MA, Thomassen MJ, Montie TC. Flagella and motility alterations in Pseudomonas aeruginosa strains from patients with cystic fibrosis: relationship to patient clinical condition. Infect Immun 1985; 50: 577-582.
50. Ferrero RL, Lee A. Motility of Campylobacter jejuni in a viscous environment: comparison with conventional rodshaped bacteria. J Gen Microbiol 1988; 134 : 53-59.

51. Karmali MA, Skirrow MB. Taxonomy of the genus Campylobacter. In: Butzler JP (ed) Campylobacter infection in man and animals. Boca Raton, FL, CRC Press, Inc. 1984: 1-20

52. Smibert RM. Genus Campyiobacter (Sebald and Veron, 1963) In: Krieg NR (ed) Bergey's manual of systematic bacteriology, vol. 1. Baltimore, The Williams and Wilkins Co. 1984: 111-118.

53. Nachamkin I, Yang X-H. Immune response to Campylobacter flagellin. In: Nachamkin I, Blaser MJ, Tompkins LS (eds) Campylobacter jejuni-current status and future trends. Washington, DC. American Society for Microbiology. 1992: 216-222.

54. Guerry P, Alm RA, Power ME, Trust T. Molecular and structural analysis of Campylobacter flagellin. In: Nachamkin I, Blaser MJ, Tompkins LS (eds) Campylobacter jejuni-current status and future trends. Washington, DC. American Society for Microbiology. 1992: 267-281. 